\title{
The Impact of Major and Trace Elements in Serum and Bone on Dual-Energy X-Ray Absorptiometry-Derived Hip Strength
}

\author{
Tomasz Miazgowski ${ }^{1} \cdot$ Aleksandra Rył ${ }^{2}$ (D) - Aleksandra Szylińska² $\cdot$ Iwona Rotter $^{2}$
}

Received: 27 October 2021 / Accepted: 5 January 2022 / Published online: 24 January 2022

(c) The Author(s) 2022

\begin{abstract}
The purpose of this study was to establish associations between both serum levels and bone content of a wide range of elements (Na, K, P, Ca, Mg, Zn, Cu, Cr, Mn, Fe, and Pb), with hip strength (HS) indices derived from dual-energy X-ray absorptiometry (DXA). The study population consisted of a number of male patients aged 56-77 years following hip replacement due to osteoarthritis of the hip. Bone specimens were taken from the femoral head and neck during arthroplasty. The elemental analyses were carried out using coupled plasma optical emission spectrometry. The following DXA-HS parameters were assessed: buckling ratio (BR), cross-sectional area (CSA) and its moment of inertia (CSMI), section modulus, and Femoral Strength Index (FSI). Age was positively correlated with $\mathrm{Na}, \mathrm{K}$, and $\mathrm{Cu}$ in the bone. $\mathrm{Ca}$ in the bone was positively associated with BR and negatively with SM and CSMI. Of all the DXA-HS parameters, the weakest associations of elements in the bone were found with FSI and the strongest with BR. Among the elements in the serum, the strongest negative associations were found for $\mathrm{K}, \mathrm{Cr}, \mathrm{Mn}$, and $\mathrm{Zn}$ with CSA, while the majority of bone elements were associated either positively $(\mathrm{Ca}, \mathrm{P}$, $\mathrm{Mg}, \mathrm{Zn}$, and $\mathrm{Cu}$ ) or negatively $(\mathrm{Mn}, \mathrm{Fe}, \mathrm{Pb}$, and $\mathrm{Cr}$ ) with $\mathrm{BR}$. In conclusion, the interactions between individual elements in blood serum and bone with DXA-HS could not be unequivocally established.
\end{abstract}

Keywords Hip strength $\cdot$ Elemental analysis $\cdot$ Bone mineral density $\cdot$ Bone health

\section{Introduction}

The load-bearing capacity of bone depends on its mass, commonly assessed by densitometry and bone quality to encompasses geometry (macroarchitecture), microarchitecture, intrinsic properties of the bone tissue, and the interactions between its elements. While bone strength is determined by genetic factors, throughout its lifespan bone tissue is able to adjust its geometrical rearrangements to the mechanical loads and strains, in addition to bone homeostasis driven by the paracrine and systemic hormonal milieu [1-3]. Through

Tomasz Miazgowski and Aleksandra Rył have contributed equally to this work.

Aleksandra Rył

aleksandra.ryl@pum.edu.pl

1 Department of Propedeutics of Internal Medicine and Arterial Hypertension, Pomeranian Medical University in Szczecin, Szczecin, Poland

2 Department of Medical Rehabilitation and Clinical Physiotherapy, Pomeranian Medical University in Szczecin, Szczecin, Poland these mechanisms, bone can modify its size (diameter and thickness), shape, and architecture (i.e., the redistribution of bone tissue) to adapt the cross-sectional area (CSA) and moment of inertia (CSMI) to the stresses [3-6]. The majority of these attributes arise from the specific composition of bone matrix [7]. Among the minerals involved in these bone processes, calcium $(\mathrm{Ca})$ and phosphorus $(\mathrm{P})$ ions (the main constituents of hydroxyapatite crystal) play a pivotal role in the acquisition and maintenance of bone strength. However, bone matrix also contains amounts of other major elements such as sodium $(\mathrm{Na})$, potassium $(\mathrm{K})$, and magnesium $(\mathrm{Mg})$, as well as trace elements such as zinc $(\mathrm{Zn})$, copper $(\mathrm{Cu})$, lead $(\mathrm{Pb})$, manganese $(\mathrm{Mn})$, chrome $(\mathrm{Cr})$, and iron $(\mathrm{Fe})$ that potentially affect bone strength. It has been suggested that some of these mechanisms might be mediated through their impact on bone mass and remodeling. For example, even mild Na deficiency leads to increased osteoclast activity and bone resorption [8,9]. One of the most promoted hypotheses for the benefit of $\mathrm{K}$ on bone homeostasis is through its effect on acid-base balance, as bone tissue turnover may increase in response to acid [10]. Zn, which is an important cofactor in metalloenzymes, may stimulate cell differentiation and 
proliferation and bone mineralization through gene expression of various proteins, including type I collagen, alkaline phosphatase, and osteocalcin [11-14]. In turn, $\mathrm{Cu}$-an enzymatic cofactor-may activate lysyl oxidase, which induces the formation of lysine crosslinks in collagen and elastin and inhibits osteoclastic resorption [15]. However, in clinical studies, the associations of $\mathrm{Cu}$ with bone mass have yielded conflicting conclusions, with positive [16], negative [17], and neutral [18]. Other trace elements may exert different effects on bone health: negative $(\mathrm{Pb}, \mathrm{Al}, \mathrm{Co}, \mathrm{Cd}$, and $\mathrm{Cr})$, positive ( $\mathrm{Si}, \mathrm{B}, \mathrm{Sr}$, and $\mathrm{Mg}$ ), or antagonistic (positive or negative) depending on their intra-osseous content $(\mathrm{Cu}, \mathrm{Li}, \mathrm{F}$, and $\mathrm{Mn})[13,19,20]$. Nonetheless, the relationship between the mineral composition of bone and its mechanical properties is poorly understood. Specifically, there have been no previous reports evaluating the role of the chemical elements present in the inorganic matrix in determining bone strength.

The purpose of this study was to establish associations of the serum levels and bone content of a wide range of elements ( $\mathrm{Na}, \mathrm{K}, \mathrm{P}, \mathrm{Ca}, \mathrm{Mg}, \mathrm{Zn}, \mathrm{Cu}, \mathrm{Cr}, \mathrm{Mn}, \mathrm{Fe}$, and $\mathrm{Pb}$ ) with the dual-energy X-ray absorptiometry (DXA)-derived indices of hip strength (HS).

\section{Material and Methods}

\section{Study Population}

The study population consisted of male patients treated at the Orthopedic Surgery Clinic of the Pomeranian Medical University due to osteoarthritis (OA) of the hip, using a routine hip replacement. We excluded patients with diabetes requiring insulin therapy, history of cancer within the preceding 5 years, liver or kidney failure, heart failure (class III or IV according to the New York Heart Association (NYHA) classification), and medications that might have potentially affected bone metabolism, such as mineral supplements, neuroleptics, chemotherapeutic agents, immunosuppressants, steroids, and antidepressants. Overall, we included 57 patients, four of whom had undergone a prior hip replacement on the opposite side. All the patients had severe OA (grade 4 according to standard Kellgren-Lawrence classification). On the opposite hip, the severity of OA was evaluated as mild to moderate (grade 2 or 3 ). The study complied with all applicable institutional regulations regarding the ethical use of human volunteers in research and the terms of the Declaration of Helsinki. The Pomeranian Medical University Ethics Committee approved the study protocol, and all participants gave their written consent.

\section{Elemental Analysis}

Serum concentrations and bone content of $\mathrm{Na}, \mathrm{K}, \mathrm{P}, \mathrm{Ca}$, $\mathrm{Mg}, \mathrm{Zn}, \mathrm{Cu}, \mathrm{Cr}, \mathrm{Mn}, \mathrm{Fe}$, and $\mathrm{Pb}$ were measured using inductively coupled plasma optical emission spectrometry (ICP-OES; iCAP 7400 Duo analyser equipped with a polypropylene cyclonic spray chamber; Thermo Fisher Scientific, Waltham, MA, USA), a well-established and powerful technique commonly used for quantification of elements in liquid and solid samples. All venous blood samples were collected following an overnight fast and stored at $-80{ }^{\circ} \mathrm{C}$ until processed. The samples were thawed to room temperature and digested using the microwave digestion system CEM MARS 5. Next, samples were transferred to polypropylene tubes and $4 \mathrm{~mL}$ of high-purity $65 \% \mathrm{HNO}_{3}$ reagent (Suprapur, Merck, Darmstadt, Germany) was added. After completion of the pre-reaction time, $1 \mathrm{~mL}$ of non-stabilized $30 \% \mathrm{H}_{2} \mathrm{O}_{2}$ solution (Suprapur, Merck, Darmstadt, Germany) was added to each vial. Once the addition of all reagents was complete, the samples were placed in special Teflon vessels and heated in a microwaved digestion system for $35 \mathrm{~min}$ at $180{ }^{\circ} \mathrm{C}\left(15 \mathrm{~min}\right.$ ramp up to $180{ }^{\circ} \mathrm{C}$ and maintained at $180^{\circ} \mathrm{C}$ for $\left.20 \mathrm{~min}\right)$. In a clean hood, samples were transferred to acid-washed $15-\mathrm{mL}$ polypropylene sample tubes. A further fivefold dilution was performed prior to ICPOES measurement and $2 \mathrm{~mL}$ was taken from each digest. The samples were then spiked with an internal standard to provide a final concentration of $0.5 \mathrm{mg} / \mathrm{L}$ Yttrium and $1 \mathrm{~mL}$ of $1 \%$ Triton (Triton X-100, Sigma) and diluted to a final volume of $10 \mathrm{~mL}$ with $0.075 \%$ nitric acid (Suprapur, Merck, Germany). Blank samples were prepared by adding concentrated nitric acid to the tubes without sample and subsequently diluted in the same manner as described above. The calibration standards (ICP multi-element standard solution IV; AccuStandard Inc., New Haven, CT, USA) and the reference material (National Institute of Standards and Technology (NIST) SRM 8414 Bovine Muscle, Gaithersburg, MD, USA) were prepared in the same manner as the samples and blanks. The limits of detection $(\mu \mathrm{g} / \mathrm{L})$ were as follows: Ca 0.003, Mn 0.07, $\mathrm{K}$ 0.6, Zn 0.19, Cu 0.39, Fe 0.25, Na 0.37, Pb 1.06, P 1.55, and $\mathrm{Mg} 0.01$.

Bone specimens were taken from the femoral head and neck following the hip arthroplasty procedure. During surgery, the soft tissues surrounding the femoral head were discarded and then the femoral head and neck were extracted from the acetabulum manually. This test material was collected and stored at $-80{ }^{\circ} \mathrm{C}$ until analysis. At analysis, samples were thawed to room temperature, dried overnight to a constant weight at $80^{\circ} \mathrm{C}$ after cleaning of all adherent tissues, ground into a powder in a porcelain 
mortar, and mineralized using a CEM MARS 5 digestion oven. All pre-analytical procedures were similar to the serum samples. Blank samples were prepared by adding concentrated nitric acid $(80 \mu \mathrm{L})$ to tubes without sample and subsequently diluted in the same manner. Bulk mineral calibration standards (ICP multi-element standard solution IV Ca, Mn, K, Zn, Cu, Fe, $\mathrm{Na}, \mathrm{Pb}, \mathrm{Cr}, \mathrm{P}, \mathrm{Mg}$; Merck, Germany; Single Element ICP Standard for K, Inorganic Ventures, Christiansburg, VA, USA) were prepared at different concentrations of inorganic elements. Samples of reference material (NIST SRM 1486 Bone Meal) were prepared in the same manner as the bone samples.

Analyses were performed in both radial and axial mode depending on the element and matrix. Multiple wavelengths were generally monitored for each element to provide confirmation of quantitative results. Continuing calibration check samples were analyzed at most after every tenth sample and consisted of a blank measurement to monitor carryover and mid-range calibration standards from both the low and high concentration calibration curves. The wavelengths $(\mathrm{nm})$ were as follows: Ca 315.887, $\mathrm{Mn}$ 257.610, K 766.490, Zn 206.200, Cu 224.700, Fe 238.204, Na 589.592, Pb 220.353, P 178.284, and $\mathrm{Mg} 280.270$.

\section{Bone Mineral Density}

BMD was measured by DXA (Lunar Prodigy Advance, enCORE software version 14.10; GE Healthcare; Madison, WI, USA). The total body BMD and bone mineral content (BMC) were assessed using the Advanced Body Assessment tool of the software system. Total neck BMD at the left and right femur was measured without reposition using the DualFemur ${ }^{\mathrm{TM}}$ scan mode on all but four of the patients with a prior hip replacement, in which a single femur scan mode on the operated side was used.

\section{Hip Strength Assessment}

HS was assessed using the Advanced Hip Structural Analysis (HSA) software package that derives the cross-sectional geometry from plain images acquired by DXA. This method uses raw spatial and mineral mass from the proximal femur to compute structural geometrical indices at three specific locations: the neck, and the intertrochanteric and proximal shaft regions. The software computes the following parameters: (1) CSMI (in $\mathrm{mm}^{4}$ ) that is used to measure the distribution of material around the neck axis necessary to calculate resistance to bending forces-mechanical stress within a cross-section subjected to bending is inversely related to the CSMI and varies with the distance from the neutral axis [21]; (2) CSA (in $\mathrm{mm}^{2}$ ), the total surface area of bone in a cross-sectional slice after excluding all the spaces occupied by marrow and other soft tissues within pores. CSA is commonly referred to as the minimal CSMI section within the neck ROI and reflects the ability of the femoral neck to withstand axial forces; (3) neck shaft angle, the angle between the femoral neck and femoral shaft (an axillary parameter, not evaluated in this study); (4) section modulus (SM), a strength parameter derived from CSMI, equal to the CSMI divided by the distance from centroidal axis to the edge of the section; (5) Femoral Strength Index (FSI), a composite unitless index that corresponds to a ratio of the estimated compressive yield strength of the femoral neck to the expected compressive stress of a fall on the greater trochanter, adjusted for age, height and weight. The greater the FSI, the lower the hip fracture risk from a fall on the greater trochanter; and (6) buckling ratio (BR), the ratio of the outer radius to the cortical thickness, which represents a means for estimating the stability of the cortex in thin-walled regions subjected to bending; a higher BR value means a greater instability and thus it makes sense that greater strength is found at regions with greater stability, i.e., lower BR. The HSA, similarly to BMD, was shown to be an independent predictor of fragility fractures [22, 23].

\section{Statistical Analysis}

Descriptive statistics were presented as means (ranges) and standard deviations (SD) for continuous variables and frequency distribution for categorical variables. Data were checked for normality using a Shapiro-Wilk test. A comparison of HS and BMD between the left and right femur was assessed using a non-parametric Mann-Whitney $U$-test. Correlations between pairs of quantitative variables were analyzed using a Pearson's linear correlation or Spearman's rho correlation for normally and non-normally distributed variables. The associations of serum and bone element levels (predictors) with HS indices (outcomes) were assessed using multiple linear regression models adjusted for age, BMI, and femur BMD. Statistical analyses were performed using Statistica (v12.0; StatSoft Poland).

\section{Results}

\section{The Study Population}

The study population comprised 57 males aged 56-77 years (Table 1). Among them, 16 were obese, and 4 had a prior hip replacement of the opposite hip. 43 patients were being treated for hypertension, 22 had benign prostatic hyperplasia, 8 had type 2 diabetes, and 4 had hyperuricemia. Two patients $(3.5 \%)$ met the DXA diagnostic criteria for osteoporosis (femur $t$-score $\leq 2.5 \mathrm{SD}$ ) and $6(10.5 \%)$ had mildly reduced BMD (femur $t$-score between -1 and -2 SDs). None of the patients had a history of previous hip fracture. 
Table 1 Baseline characteristics of study participants $(n=57)$

\begin{tabular}{llcc}
\hline & Mean & SD & Range \\
\hline Age [years] & 66.70 & 4.967 & $56.0-77.0$ \\
Height $[\mathrm{cm}]$ & 175.1 & 15.22 & $165-193$ \\
Weight [kg] & 89.87 & 7.824 & $73.0-112.5$ \\
Body mass index $\left[\mathrm{kg} / \mathrm{m}^{2}\right]$ & 30.03 & 3.392 & $22.77-37.88$ \\
Current smokers $(n ; \%)$ & $6(10.5 \%)$ & & \\
Hypertension, $n(\%)$ & $43(75.4 \%)$ & & \\
Diabetes, $n(\%)$ & $8(14.0 \%)$ & & \\
Hyperuricemia, $n(\%)$ & $4(7.0 \%)$ & & \\
Benign prostatic hyperplasia, $n(\%)$ & $22(38.6 \%)$ & & \\
Obesity, $n(\%)$ & $16(28.1 \%)$ & & \\
Operated femur $($ left $/$ right $)$ & $29(50.9 \%) / 28(49.1 \%)$ & & \\
Total bone mineral density $\left[\mathrm{g} / \mathrm{cm}^{2}\right]$ & 1.270 & 0.155 & $0.991-1.555$ \\
Bone mineral content $[\mathrm{kg}]$ & 3.089 & & $2.086-4.012$ \\
\hline
\end{tabular}

Table 2 Concentration of serum elements

\begin{tabular}{lcccc}
\hline & Mean & SD & Range & Reference range $^{\mathrm{a}}$ \\
\hline $\mathrm{Na}[\mathrm{mg} / \mathrm{L}]$ & 3395 & 453.6 & $2518-4760$ & $3103-3402$ \\
$\mathrm{~K}[\mathrm{mg} / \mathrm{L}]$ & 204.4 & 51.09 & $130-350$ & $149-215$ \\
$\mathrm{Ca}[\mathrm{mg} / \mathrm{L}]$ & 112.8 & 6.660 & $86-147$ & $91-106$ \\
$\mathrm{P}[\mathrm{mg} / \mathrm{L}]$ & 219.3 & 59.38 & $130-342$ & $85.9-246$ \\
$\mathrm{Zn}[\mathrm{mg} / \mathrm{L}]$ & 1.395 & 0.368 & $0.84-2.35$ & $0.70-1.20$ \\
$\mathrm{Cu}[\mathrm{mg} / \mathrm{L}]$ & 0.992 & 0.150 & $0.69-1.46$ & $0.80-1.50$ \\
$\mathrm{Fe}[\mathrm{mg} / \mathrm{L}]$ & 1.500 & 0.389 & $0.80-2.51$ & $0.70-1.500$ \\
$\mathrm{Cr}[\mathrm{mg} / \mathrm{L}]$ & 0.008 & 0.002 & $0.003-0.01$ & $0.001-0.041$ \\
$\mathrm{Mg}[\mathrm{mg} / \mathrm{L}]$ & 25.80 & 3.742 & $16.9-38.2$ & $17.0-22.0$ \\
$\mathrm{Mn}[\mathrm{mg} / \mathrm{L}]$ & 0.009 & 0.003 & $0.006-0.02$ & $0.005-0.018$ \\
$\mathrm{~Pb}[\mu \mathrm{g} / \mathrm{L}]$ & 0.724 & 0.099 & $0.62-0.82$ & $0.033-6.325$ \\
\hline
\end{tabular}

${ }^{a}$ Reference ranges from ref $[24,25]$

Table 3 Bone elements

\begin{tabular}{lccl}
\hline & Mean & SD & Range \\
\hline $\mathrm{Na}[\mathrm{g} / \mathrm{kg}]$ & 9.359 & 3.027 & $3.130-13.94$ \\
$\mathrm{~K}[\mathrm{mg} / \mathrm{kg}]$ & 839.7 & 389.1 & $71.25-1581.8$ \\
$\mathrm{Ca}[\mathrm{g} / \mathrm{kg}]$ & 262.6 & 80.49 & $87.54-392.8$ \\
$\mathrm{P}[\mathrm{g} / \mathrm{kg}]$ & 143.6 & 42.95 & $64.74-262.0$ \\
$\mathrm{Zn}[\mathrm{mg} / \mathrm{kg}]$ & 195.7 & 53.34 & $68.08-306.4$ \\
$\mathrm{Cu}[\mathrm{mg} / \mathrm{kg}]$ & 1.439 & 0.898 & $0.624-4.185$ \\
$\mathrm{Fe}[\mathrm{mg} / \mathrm{kg}]$ & 162.9 & 243.8 & $0.585-1123$ \\
$\mathrm{Cr}[\mathrm{mg} / \mathrm{kg}]$ & 1.669 & 2.813 & $0.242-10.91$ \\
$\mathrm{Mg}[\mathrm{g} / \mathrm{kg}]$ & 3.538 & 1.001 & $1.220-5896$ \\
$\mathrm{Mn}[\mathrm{mg} / \mathrm{kg}]$ & 0.760 & 1.253 & $0.101-5.130$ \\
$\mathrm{~Pb}[\mathrm{mg} / \mathrm{kg}]$ & 2.797 & 1.397 & $0.788-5.718$ \\
\hline
\end{tabular}

The levels of the elements in the serum and bone are presented in Tables 2 and 3, respectively. The mean values of elements in the serum were within ICP-OES reference ranges in literature [24, 25]. The levels of the elements in the bone were in the following descending order: $\mathrm{Ca}(62.4 \%$ of total elements $)>\mathrm{P}(34.1 \%)>\mathrm{Mg}>\mathrm{K}>\mathrm{Zn}>\mathrm{Fe}>\mathrm{Pb}>\mathrm{Cr}>$ $\mathrm{Cu}>\mathrm{Mn}$. The mean values of femur BMD, $t$-score, $z$-score, and all HS parameters (calculated for 53 patients who had no prior hip replacement) did not differ significantly in comparison between the operated and non-operated side ( $p>0.1$ for all comparisons). As expected, femur BMD was significantly correlated with all strength indices. The strongest associations were with CSA $(r=0.853 ; p=0.001)$ followed by SM $(r=0.635 ; p=0.001)$, CSMI $(r=0.473 ; p=0.001)$, $\mathrm{BR}(r=-0.305 ; p=0.033)$, and FSI $(r=0.301 ; p=0.035)$.

\section{Associations of Elements in the Serum with Bone Mass and Hip Strength}

Serum Ca concentration did not correlate with either BMD or HS (Table 4). A similar lack of correlation was also found for the other major elements, apart from serum P level, which was weakly but significantly associated with FSI. From among the trace elements, Fe level was correlated with CSA, BMD, and BMC, and Mn level with BMD and BMC. However, after adjusting for age, BMI, and femur BMD, these associations were no longer significant (Table 5). Instead, serum $\mathrm{Cr}, \mathrm{Mn}, \mathrm{K}$, and $\mathrm{Zn}$ were found to be significant, negatively correlated determinants of HS parameters. In contrast, serum $\mathrm{P}$ concentration was positively associated with HS (but only in relation to CSMI).

In comparison with serum and bone levels, $\mathrm{Na}$ and $\mathrm{Cu}$ were significantly correlated $(r=0.421 ; p=0.007$ and $r=0.363 ; p=0.021$, respectively), while the other elements were not. After adjusting for age, smoking, and total $\mathrm{BMD}$, serum and bone levels of $\mathrm{Na}$ and $\mathrm{K}$ were positively associated, and for Fe levels, the association was negative (Table 6). 
Table 4 Correlations of serum elements with bone indices

\begin{tabular}{lllllrrrr}
\hline & FSI & Buckling ratio & Section modulus & CSMI & CSA & Femur BMD & Total BMD & Total BMC \\
\hline $\mathrm{Na}$ & -0.050 & -0.167 & -0.082 & -0.153 & 0.023 & 0.176 & 0.211 & 0.225 \\
$\mathrm{~K}$ & -0.292 & 0.224 & -0.248 & -0.223 & -0.082 & 0.209 & 0.221 & 0.155 \\
$\mathrm{Ca}$ & 0.176 & -0.222 & 0.023 & 0.001 & 0.191 & 0.216 & 0.312 & 0.301 \\
$\mathrm{P}$ & $0.358^{\mathrm{a}}$ & 0.176 & 0.222 & 0.260 & 0.045 & -0.117 & -0.152 & -0.127 \\
$\mathrm{Zn}$ & -0.329 & 0.120 & -0.189 & -0.239 & -0.036 & 0.234 & 0.301 & 0.209 \\
$\mathrm{Cu}$ & -0.253 & -0.133 & -0.137 & -0.160 & -0.177 & -0.108 & -0.083 & -0.109 \\
$\mathrm{Fe}$ & 0.125 & -0.334 & 0.280 & 0.280 & $0.442^{\mathrm{b}}$ & $0.410^{\mathrm{a}}$ & $0.524^{\mathrm{b}}$ & $0.557^{\mathrm{b}}$ \\
$\mathrm{Cr}$ & 0.020 & 0.130 & -0.066 & -0.081 & -0.082 & 0.065 & 0.048 & -0.022 \\
$\mathrm{Mg}$ & -0.223 & 0.136 & -0.232 & -0.271 & -0.083 & 0.155 & 0.183 & 0.121 \\
$\mathrm{Mn}$ & -0.198 & 0.223 & -0.006 & -0.063 & 0.127 & $0.333^{\mathrm{a}}$ & $0.419^{\mathrm{a}}$ & 0.298 \\
$\mathrm{~Pb}$ & -0.892 & 0.117 & -0.192 & -0.094 & -0.114 & -0.109 & -0.202 & -0.198 \\
\hline
\end{tabular}

${ }^{\mathrm{a}} p<0.05 ;{ }^{\mathrm{b}} p<0.01$

Table 5 Associations of serum elements with HS

\begin{tabular}{llllll}
\hline & Hip strength index & \multicolumn{4}{l}{ Adjusted for age, BMI and femur BMD } \\
\cline { 3 - 6 } & & Beta & $p$-value & $95 \%$ CI & \\
\hline \multirow{2}{*}{ Zn } & Section modulus & -0.397 & 0.028 & -0.750 & -0.044 \\
& CSA & -0.799 & 0.001 & -1.240 & -0.358 \\
\multirow{2}{*}{ Mn } & Section modulus & -0.568 & 0.001 & -0.906 & -0.230 \\
& CSMI & -0.404 & 0.011 & -0.713 & -0.096 \\
& CSA & -0.806 & 0.001 & -1.255 & -0.357 \\
Cr & Section modulus & -0.561 & 0.003 & -0.915 & -0.208 \\
& CSMI & -0.413 & 0.013 & -0.734 & -0.093 \\
& CSA & -0.810 & 0.001 & -1.279 & -0.342 \\
K & Buckling ratio & 0.316 & 0.034 & 0.026 & 0.607 \\
& Section modulus & -0.573 & 0.002 & -0.916 & -0.230 \\
& CSMI & -0.381 & 0.021 & -0.702 & -0.060 \\
& CSA & -0.842 & 0.001 & -1.295 & -0.389 \\
P & CSMI & 0.323 & 0.031 & 0.031 & 0.614 \\
\hline
\end{tabular}

Table 6 Serum vs. bone element concentration adjusted for age, smoking and total BMD

\begin{tabular}{lllll}
\hline & Beta & $95 \% \mathrm{CI}$ & & $p$-value \\
\hline $\mathrm{Ca}$ & 0.067 & -0.261 & 0.396 & 0.680 \\
$\mathrm{P}$ & -0.057 & -0.057 & -0.344 & 0.692 \\
$\mathrm{Na}$ & 0.168 & 0.086 & 0.765 & 0.015 \\
$\mathrm{~K}$ & 0.434 & 0.049 & 0.819 & 0.028 \\
$\mathrm{Zn}$ & -0.034 & -0.034 & -0.360 & 0.836 \\
$\mathrm{Cu}$ & 0.205 & -0.101 & 0.511 & 0.183 \\
$\mathrm{Fe}$ & -0.573 & -0.872 & -0.273 & 0.001 \\
$\mathrm{Cr}$ & -0.255 & -0.601 & 0.090 & 0.143 \\
$\mathrm{Mg}$ & -0.005 & -0.346 & 0.337 & 0.979 \\
$\mathrm{Mn}$ & -0.150 & -0.530 & 0.231 & 0.431 \\
$\mathrm{~Pb}$ & 0.101 & 0.026 & 0.142 & 0.058 \\
\hline
\end{tabular}

\section{Associations of Elements in the Bone with Bone Mass and Hip Strength}

Age was positively correlated only with bone content of $\mathrm{Na}(r=0.312 ; p=0.047), \mathrm{K}(r=0.619 ; p=0.001)$, and $\mathrm{Cu}(r=0.395 ; p=0.011)$. BMI was correlated with $\mathrm{Mn}$ $(r=0.442 ; p=0.004)$ and Fe content $(r=0.447 ; p=0.003)$. No other significant interactions of age and BMI with elements in bone were observed.

As shown in Table 7, Na content in bone was negatively correlated with BR and positively with BMC. Other significant associations included a negative correlation of $\mathrm{K}$ with FSI; Ca negatively with BR and positively with BMD and BMC; P positively with FSI and CSMI and negatively with FSI, BR, SM, and CSMI; Zn negatively with BR; $\mathrm{Cu}$ and $\mathrm{Cr}$ negatively with FSI; Mg negatively with BR and positively with BMD and BMC; and Mn negatively with $\mathrm{BR}$. Of all the studied elements, only bone $\mathrm{Fe}$ and $\mathrm{Pb}$ were not correlated with BMD and HS parameters. However, after adjustment for age and BMI (Table 8), Ca, P, Mg, Na, and $\mathrm{Zn}$ were inversely associated with BR (a positive effect on buckling resistance) with the strongest effects of $\mathrm{P}$ and $\mathrm{Zn}(\beta<-0.5) . \mathrm{Mn}, \mathrm{Fe}, \mathrm{Pb}$, and $\mathrm{Cr}$ were associated with a negative effect on buckling strength. Of other HS parameters, CSMI was negatively associated with bone $\mathrm{P}$ and $\mathrm{K}$, and the FSI with $\mathrm{Cu}$ and $\mathrm{Cr}$ (a negative relationship). Importantly, most relationships between bone elements and HS remained significant after further adjustment for BMD, particularly those with BR. In addition, Ca content showed an ambivalent relationship with HS parameters: either positive (in relation to buckling resistance) or negative (to SM and CSMI). A similar pattern was followed by $\mathrm{P}, \mathrm{Zn}$, and $\mathrm{Mg}$. The remaining major elements ( $\mathrm{Na}$ and K) were associated only with SM and CSMI. Generally, of all DXA-HSA parameters, the weakest associations of 
Table 7 Correlations of bone elements with bone strength indices and BMD

\begin{tabular}{lllllrrrr}
\hline & FSI & Buckling ratio & Section modulus & CSMI & CSA & Femur BMD & Total BMD & Total BMC \\
\hline $\mathrm{Na}$ & -0.197 & $-0.461^{\mathrm{b}}$ & 0.007 & -0.081 & 0.141 & 0.302 & 0.315 \\
$\mathrm{~K}$ & $-0.345^{\mathrm{a}}$ & -0.236 & -0.173 & -0.219 & -0.186 & -0.088 & -0.080 & -0.088 \\
$\mathrm{Ca}$ & -0.136 & $-0.444^{\mathrm{b}}$ & 0.035 & -0.043 & 0.190 & $0.382^{\mathrm{a}}$ & $0.364^{\mathrm{a}}$ & $0.424^{\mathrm{b}}$ \\
$\mathrm{P}$ & $0.371^{\mathrm{a}}$ & $-0.432^{\mathrm{a}}$ & $-0.359^{\mathrm{a}}$ & $-0.414^{\mathrm{a}}$ & -0.292 & -0.001 & 0.170 & 0.077 \\
$\mathrm{Zn}$ & -0.235 & $-0.500^{\mathrm{a}}$ & -0.053 & -0.121 & 0.098 & 0.282 & 0.241 & 0.314 \\
$\mathrm{Cu}$ & $-0.420^{\mathrm{a}}$ & -0.278 & -0.151 & -0.267 & -0.245 & -0.224 & -0.153 & -0.175 \\
$\mathrm{Fe}$ & -0.134 & 0.260 & 0.049 & 0.059 & -0.059 & -0.004 & -0.002 & -0.001 \\
$\mathrm{Cr}$ & $-0.383^{\mathrm{a}}$ & -0.312 & -0.181 & -0.292 & -0.283 & -0.305 & -0.263 & -0.255 \\
$\mathrm{Mg}$ & -0.187 & $-0.465^{\mathrm{a}}$ & -0.019 & -0.100 & 0.145 & $0.343^{\mathrm{a}}$ & 0.329 & $0.393^{\mathrm{a}}$ \\
$\mathrm{Mn}$ & -0.111 & $0.345^{\mathrm{a}}$ & 0.007 & 0.025 & -0.049 & -0.040 & -0.041 & 0.049 \\
$\mathrm{~Pb}$ & -0.059 & -0.246 & -0.068 & -0.145 & -0.016 & 0.100 & 0.046 & 0.098 \\
\hline
\end{tabular}

${ }^{\mathrm{a}} \mathrm{p}<0.05 ;{ }^{\mathrm{b}} \mathrm{p}<0.01$

the elements in bone were found to be with FSI and the strongest with BR.

The mean value of the $\mathrm{Ca} / \mathrm{P}$ ratio in bone was $1.908 \pm 0.21$ and was not associated with any of the HS indices after adjusting for age, BMI, and BMD. When BMD was removed from the regression model, the associations remained insignificant.

\section{Discussion}

The vast majority of existing studies assessed the role of elements in maintaining bone health by using serum concentrations in relation to BMD, bone turnover, or susceptibility to fractures. This is the first study that provides new insights into in vivo bone strength using a comprehensive analysis of both serum and bone levels of elements in relation to DXA-HS. We found that although BMD was strongly correlated with CSA and SM, its relation with other HS indices, especially BR and FSI, was relatively weaker suggesting that aside from BMD other factors may contribute to bone strength. Indeed, although BMD is a good indicator of bone mass and resistance to external and internal forces, in quantitative terms, BMD is predominantly a measure of the mineral compound calcium hydroxyapatite $[1,21$, 22], which has the formula $\mathrm{Ca}_{10}\left(\mathrm{PO}_{4}\right)_{6}(\mathrm{OH})_{2}$; however, extracellular inorganic bone matrix also contains other nonphosphate calcium compounds (e.g., calcium carbonate) as well as other chemical elements that are not measurable by conventional DXA [1,22]. Our study demonstrated a lack of association of serum calcium with the BMD (both total and femur), $\mathrm{BMC}$, and $\mathrm{HS}$ indices. By contrast, bone $\mathrm{Ca}$ content was positively associated with BMD, BMC, and HS, and although the association with HS was limited solely to buckling resistance, it remained significant even after controlling for confounders. This may indicate that most of the strengthening effects of bone $\mathrm{Ca}$ are driven by hydroxyapatite density and are limited to withstanding buckling rather than compressive and axial forces applied to the femur. Moreover, we found that serum and bone Ca levels were not correlated. Taken together, these findings suggest that in males over 55 , bone-bound $\mathrm{Ca}$ is regulated by local mechanisms, which likely are independent of serum concentrations, at least in subjects without overt osteoporosis and normal $\mathrm{Ca}$ serum levels. If so, a high $\mathrm{Ca}$ ingestion (unintended or in supplements) would not necessarily improve bone health. This suggestion is consistent with an earlier meta-analysis reporting the poor efficacy of Ca supplementation in older males [26].

Phosphorus, another main component of hydroxyapatite crystals, when measured in serum and bone, displayed ambiguous associations with HS. Serum P was positively associated with CSMI but not with BMD or other HS parameters. The bone content of $\mathrm{P}$ was negatively associated with CSMI, and also with BR after corrections for confounders. An interpretation of these findings seems uncertain. It has been suggested that the $\mathrm{Ca} / \mathrm{P}$ ratio in bone compared to each element separately might be a better indicator of variation in BMD as it can be driven by changes in either $\mathrm{Ca}$ or $\mathrm{P}$ individually or dissimilar changes in both [27, 28]. However, our results indicate that this suggestion does not apply to HS. Therefore, further studies are needed to establish the role of the $\mathrm{Ca} / \mathrm{P}$ ratio in determining bone strength.

Aside from $\mathrm{Ca}$ and $\mathrm{P}$, other major elements were also found to be associated with HS. Potassium is a ubiquitous element, but its role in bone homeostasis remains unclear. It was shown that supplementation with potassium citrate may enhance $\mathrm{Ca}$ absorption as well as decrease urinary $\mathrm{Ca}$ excretion, bone resorption markers, and serum PTH level [20, 29, 30]. On the other hand, several studies could not demonstrate any beneficial effects of long-term potassium citrate supplementation on bone turnover and BMD [31], supporting 
Table 8 Associations of bone elements with HS

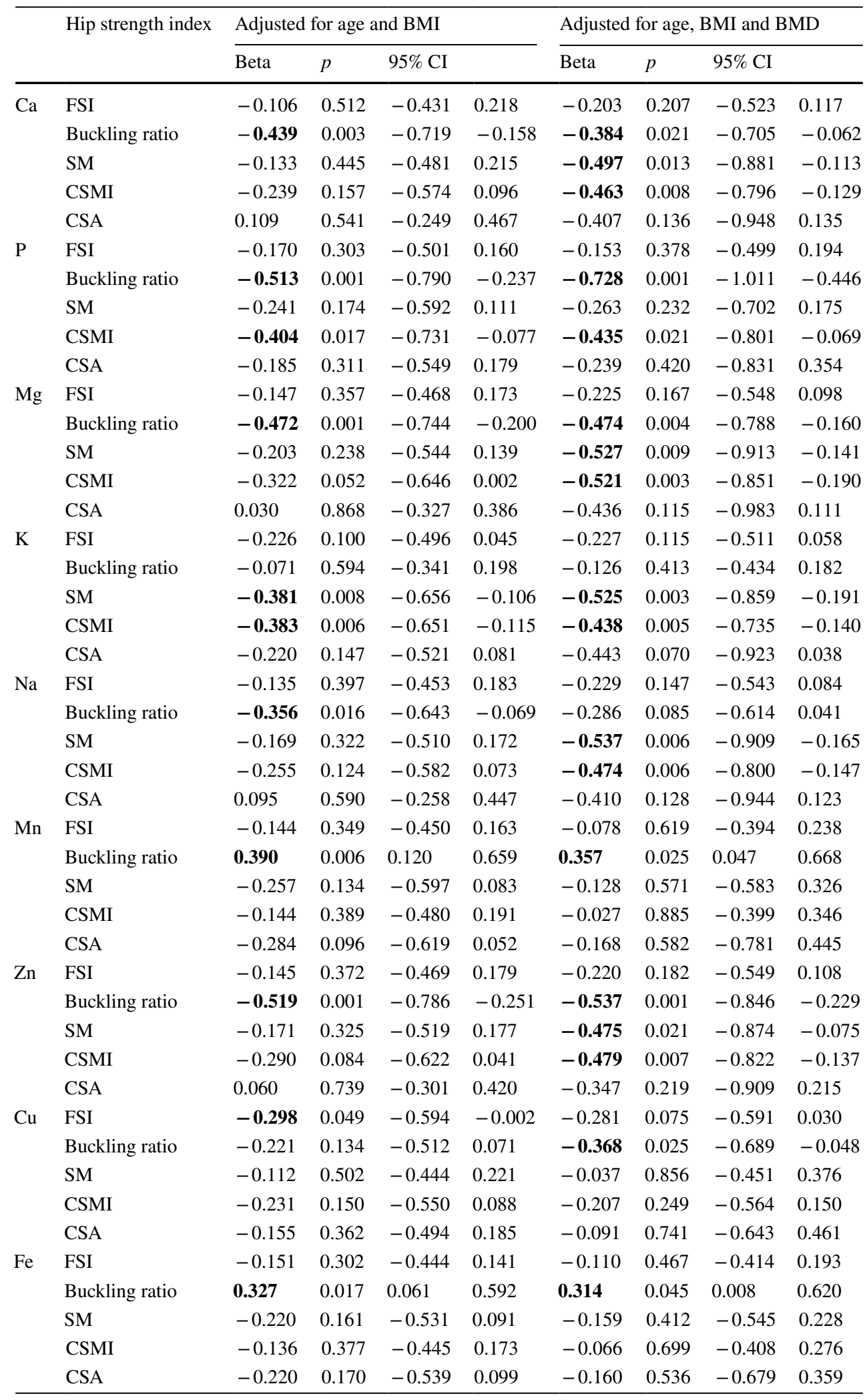


Table 8 (continued)

\begin{tabular}{|c|c|c|c|c|c|c|c|c|c|}
\hline & \multirow[t]{2}{*}{ Hip strength index } & \multicolumn{4}{|c|}{ Adjusted for age and BMI } & \multicolumn{4}{|c|}{ Adjusted for age, BMI and BMD } \\
\hline & & Beta & $p$ & $95 \% \mathrm{CI}$ & & Beta & $p$ & $95 \% \mathrm{CI}$ & \\
\hline \multirow[t]{5}{*}{$\mathrm{Pb}$} & FSI & -0.036 & 0.825 & -0.359 & 0.288 & -0.092 & 0.622 & -0.213 & 0.196 \\
\hline & Buckling ratio & 0.339 & 0.024 & 0.631 & 0.047 & 0.334 & 0.042 & 0.629 & 0.056 \\
\hline & SM & -0.218 & 0.204 & -0.558 & 0.123 & -0.040 & 0.792 & -0.866 & 0.445 \\
\hline & CSMI & -0.312 & 0.059 & -0.638 & 0.013 & -0.116 & 0.274 & -0.496 & 0.293 \\
\hline & CSA & -0.153 & 0.387 & -0.506 & 0.200 & -0.199 & 0.325 & -0.450 & 0.411 \\
\hline \multirow[t]{5}{*}{$\mathrm{Cr}$} & FSI & -0.306 & 0.049 & -0.609 & -0.002 & -0.234 & 0.075 & -0.631 & 0.033 \\
\hline & Buckling ratio & 0.304 & 0.040 & -0.594 & -0.014 & 0.491 & 0.003 & -0.801 & -0.181 \\
\hline & SM & -0.122 & 0.483 & -0.472 & 0.227 & -0.032 & 0.781 & -0.466 & 0.402 \\
\hline & CSMI & -0.251 & 0.137 & -0.585 & 0.083 & -0.219 & 0.241 & -0.591 & 0.153 \\
\hline & CSA & -0.167 & 0.343 & -0.518 & 0.184 & -0.078 & 0.781 & -0.645 & 0.489 \\
\hline
\end{tabular}

Significant associations are bolded

SM section modulus, CSMI cross-sectional moment of inertia, CSA cross-sectional area

a suggestion that bone metabolism seems to be relatively insensitive to imbalances in total body potassium [20]. Nevertheless, our study demonstrated negative associations of both serum and bone $\mathrm{K}$ with CSMI, SM, and buckling strength, suggesting a detrimental effect of potassium on HS. A similar role can be attributed to sodium and magnesium. Physiologically, sodium is the extracellular counterpart of $\mathrm{K}$. It is generally believed that bone disease is not associated with Na deficiency or excess [9,20], although some studies have demonstrated the impact of hyponatremia on the risk of osteoporosis in rats and older humans [32]. In our study, under normal serum level, sodium in bone was inversely associated with BR, SM, and CSMI. Whether or not these associations play any role in a hyponatremic state remains unknown and warrants future studies. Magnesium, which is an integral component of the apatite crystals, supports the production of hydroxyapatite, bone marrow stromal cells mineralization, and 1,25(OH)2D vitamin synthesis [33]. We found serum $\mathrm{Mg}$ not to be associated with any of the bone indices. In contrast, bone $\mathrm{Mg}$ was positively correlated with $\mathrm{BMC}$ and femur BMD and negatively with BR. The relationship with BR remained significant after correcting for confounders. However, bone $\mathrm{Mg}$ was negatively associated with SM and CSMI; therefore, the net effect of Mg on HS seems ambiguous.

Among the trace elements, manganese plays numerous roles as a cofactor in the formation of bone collagen as well as bone mineralization [13], but on the other hand, Mn overload can impair bone development, in addition to neurotoxicity, its major side effect [20]. We found Mn not to be associated with BMD and BMC. In contrast, the element was negatively associated with HS regardless of age, BMI, and femur BMD. These effects were observed for Mn both in serum (in relation to SM, CSMI, and CSA) and bone (solely to BR). Therefore, despite both the acute toxicity and chronic neurotoxicity of $\mathrm{Mn}$ resulting from high daily intake in humans being rare [20], our results suggest that the accumulation of $\mathrm{Mn}$ in bone might be deleterious to bone strength. Another trace mineral, chromium, is known from animal models and in vitro studies to induce oxidative stress and cytotoxic effects on bone cells leading to accelerated bone resorption [34, 35]. Cr-related acute intoxication in humans is rare from environmental exposure; however, in long-term exposure, $\mathrm{Cr}$ accumulation can lead to a higher susceptibility to fractures [20] and, as suggested by this study, possibly also a reduction in bone strength, especially in response to buckling forces. $\mathrm{Zn}$ behaved similarly to $\mathrm{Mg}$ on HS: $\mathrm{Zn}$ bone content was significantly positively associated with BR and negatively with SM and CSMI, and in contrast to $\mathrm{Mg}$, serum $\mathrm{Zn}$ was strongly negatively associated with CSA. Interestingly, although earlier studies evaluating associations of $\mathrm{Zn}$ with BMD yielded inconsistent conclusions [18, 19, 36], our results indicate that at least some of the effects of $\mathrm{Zn}$ on HS could be mediated independently of BMD. Similar discrepancies exist for $\mathrm{Cu}$ in determining BMD and fracture risk [13-18]. In this study, serum $\mathrm{Cu}$ was poorly correlated with $\mathrm{HS}$, while bone $\mathrm{Cu}$ was negatively associated with FSI, and after adjusting for BMD, $\mathrm{Cu}$ was positively associated with buckling strength.

In the remaining trace elements, bone $\mathrm{Fe}$ and $\mathrm{Pb}$ were inversely associated with BR. In addition, serum Fe correlated positively with BMD (both femur and total), BMC, and CSA; however, after correcting for confounders, the associations were no longer significant. Iron in normal concentrations regulates bone turnover. However, the beneficial $\mathrm{Fe}$ concentration window is relatively narrow and $\mathrm{Fe}$ overload may intensify bone resorption and oxidative stress, as well as reduce bone biomechanical properties [20, 33, 37]. Lead, in turn, easily accumulates in bones even at a low level of exposure and is believed to be highly cytotoxic to 
the bone tissue, affecting osteoblasts, osteoclasts, and chondrocytes [20, 38]. Importantly, in our study, both elements were noticeably associated with diminished femur strength, despite their serum levels being normal.

In this study, serum and bone analyses of all the elements were performed after adjustments for age, BMI, and BMD. Such adjustments are significant as the concentrations of some elements depended on age $(\mathrm{Na}, \mathrm{K}$, and $\mathrm{Cu})$ and $\mathrm{BMI}$ (Fe and $\mathrm{Mn}$ ), as well as on BMD and DXA-HS indices in similar studies [22, 23].

This study had some limitations. Firstly, a major limitation of HSA with DXA is the two-dimensional nature of DXA. This method is incapable of measuring material volume, composition, or structural design of cortical and trabecular bone, as well as the muscular and genetic contributions to bone strength. Hence, areal BMD may explain only $50-70 \%$ of variation in bone strength [3]. In addition, HSA is highly sensitive to positioning, and even small changes in femur rotation have a large effect on the projected dimensions from which the femur geometry is measured [22]. To minimize these uncertainties in this study, all scans and analyses were verified by a single trained technician. Secondly, bone samples were treated with solvents in order to remove collagen, fat, and marrow before the studied elements were quantified using ICP-OES. It has been suggested that some elements are lost by this process and their content in bone might be also affected [39]. Thirdly, apart from the $\mathrm{Ca} / \mathrm{P}$ ratio, all elements were evaluated separately. In the mineralized extracellular matrix, they may be present as part of different chemical compounds and in different ratios. In this context, elements may exert either beneficial or detrimental effects on bone homeostasis depending on their concentration as well as their interactions between individual elements [33]. Fourthly, due to limitations in the methods used in this study, we did not assess the water content of the bone, which is an integral constituent that influences the mechanical properties of bone. Approximately $20 \%$ of the cortical bone consists of water, which is bound to the collagenous structure, embedded in the crystal lattice and freely residing in the network of pores, playing an important role in matrix mineralization and overall bone resistance [40, 41]. Finally, bone samples were obtained from patients with hip OA, and hence, our findings may not apply to healthy individuals or patients with other bone disorders, as hip OA is associated with chronic inflammatory state that involves auricular cartilage, subchondral cortical and trabecular bone, and synovium, leading to articular cartilage stress distribution changes with subchondral bone expansion. Although in the studied cohort OA lesions were bilateral (but more severe on the operated side), bone parameters were comparable between the operated and intact femurs suggesting that the severity of OA had no essential impact on BMD and HS. In contrast, patients with $\mathrm{OA}$ frequently have higher femur
BMD in comparison with controls, likely with the exception of a subset of patients with atrophic OA [42]. It is believed that higher BMD in OA may reflect a process known as buttressing, whereby osteophytes extend across the femoral neck, causing artefactual increases in bone mass measured by DXA [43]. Nonetheless, it is still unknown whether these changes in bone mass affect bone strength in OA patients.

In summary, the interactions between the individual elements in the blood serum and bone measured using DXAHS indices could not unequivocally be established. Among the elements in the serum, the strongest negative associations with CSA were found for $\mathrm{K}, \mathrm{Cr}, \mathrm{Mn}$, and $\mathrm{Zn}$, while for buckling resistance, the majority of bone elements were associated either positively $(\mathrm{Ca}, \mathrm{P}, \mathrm{Mg}, \mathrm{Zn}$, and $\mathrm{Cu})$ or negatively ( $\mathrm{Mn}, \mathrm{Fe}, \mathrm{Pb}$, and $\mathrm{Cr}$ ).

Author Contributions Data conceptualization and Review and editing were done by TM, AR, and IR; data interpretation was performed by $\mathrm{TM}, \mathrm{AR}$, and AS; Original draft preparation was done by TM and AR; funding acquisition was carried out by AR and IR. All authors reviewed and approved the final version of the manuscript.

Funding This study was supported by a research grant obtained from the Pomeranian Medical University in Szczecin (grant No. WNoZ-321-01/S/01/21).

Data Availability The data presented in this study are available on request from the corresponding author.

\section{Declarations}

Conflict of interest The authors declare that they have no conflict of interest.

Ethical Approval The study complied with all applicable institutional regulations regarding the ethical use of human volunteers in research and the terms of the Declaration of Helsinki. The Pomeranian Medical University Ethics Committee approved the study protocol.

Informed Consent Informed consent was obtained from all of the subjects participating in the study.

Open Access This article is licensed under a Creative Commons Attribution 4.0 International License, which permits use, sharing, adaptation, distribution and reproduction in any medium or format, as long as you give appropriate credit to the original author(s) and the source, provide a link to the Creative Commons licence, and indicate if changes were made. The images or other third party material in this article are included in the article's Creative Commons licence, unless indicated otherwise in a credit line to the material. If material is not included in the article's Creative Commons licence and your intended use is not permitted by statutory regulation or exceeds the permitted use, you will need to obtain permission directly from the copyright holder. To view a copy of this licence, visit http://creativecommons.org/licenses/by/4.0/. 


\section{References}

1. Alcorta-Sevillano N, Macías I, Infante A, Rodríguez CI (2020) Deciphering the relevance of bone ECM signaling. Cells 9(12):2630. https://doi.org/10.3390/cells9122630

2. Fan Y, Fan Y, Li Z, Loan M, Lv C, Bo Z (2011) Optimal principle of bone structure. PLoS ONE 6(12):e28868. https://doi.org/10. 1371/journal.pone. 0028868

3. Hart NH, Nimphius S, Rantalainen T, Ireland A, Siafarikas A, Newton RU (2017) Mechanical basis of bone strength: influence of bone material, bone structure and muscle action. J Musculoskelet Neuronal Interact 17(3):114-139

4. Seeman E (2008) Bone quality: the material and structural basis of bone strength. J Bone Miner Metab 26(1):1-8. https://doi.org/ 10.1056/NEJMra053077

5. Warden SJ, Mantila Roosa SM, Kersh ME, Hurd AL, Fleisig GS, Pandy MG, Fuchs RK (2014) Physical activity when young provides lifelong benefits to cortical bone size and strength in men. Proc Natl Acad Sci USA 111(14):5337-5342. https://doi. org/10.1073/pnas.1321605111

6. Warden SJ, Wright CS, Fuchs RK (2021) Bone microarchitecture and strength adaptation to physical activity: a withinsubject controlled HRpQCT Study. Med Sci Sports Exer 53(6):1179-1187. https://doi.org/10.1249/MSS.0000000000 002571

7. Unal M, Creecy A, Nyman JS (2018) The role of matrix composition in the mechanical behavior of bone. Curr Osteoporos Rep 16:205-215. https://doi.org/10.1007/s11914-018-0433-0

8. Barsony J, Sugimura Y, Verbalis J (2011) Osteoclast response to low extracellular sodium and the mechanism of hyponatremiainduced bone loss. J Biol Chem 286:10864-10875. https://doi. org/10.1074/jbc.M110.155002

9. Hannon MJ, Verbalis JG (2014) Sodium homeostasis and bone. Curr Opin Nephrol Hypertens 23:370-376. https://doi.org/10. 1097/01.mnh.0000447022.51722.f4

10. Weaver CM (2014) Potassium and health. Adv Nutr 4:368S-377S. https://doi.org/10.3945/an.112.003533

11. Yamaguchi M, Uchiyma S (2004) Receptor activator of Nf-jB ligand (RANKL)-stimulated osteoclastogenesis in mouse marrow culture is suppressed by zinc in vitro. Int J Mol Med 14:81-85. https://doi.org/10.3892/ijmm.14.1.81

12. Alhava EM, Olkkonen H, Puittinen J, Nokso-Koivisto VM (1977) Zinc content of human cancellous bone. Acta Orthop Scand 48(1):1-4. https://doi.org/10.3109/17453677708985102

13. Pepa GD, Brandi ML (2016) Microelements for bone boost: the last but not the least. Clin Cases Miner Bone Metab 13(3):181185. https://doi.org/10.11138/ccmbm/2016.13.3.181

14. Mahdavi-Roshan M, Ebrahimi M, Ebrahimi A (2015) Copper, magnesium, zinc and calcium status in osteopenic and osteoporotic post-menopausal women. Clin Cases Miner Bone Metab 12(1):18-21. https://doi.org/10.11138/ccmbm/2015.12.1.018

15. Razmandeh R, Nasli-Esfahani E, Heydarpour R, Faridbod F, Ganjali MR, Norouzi P (2014) Association of zinc, copper and magnesium with bone mineral density in Iranian postmenopausal women: a case control study. J Diabetes Metab Disord 13(1):43. https://doi.org/10.1186/2251-6581-13-43

16. Qu X, He Z, Qiao H, Zhai Z, Mao Z, Yu Z, Dai K (2018) Serum copper levels are associated with bone mineral density and total fracture. J Orthop Translat 14:34-44. https://doi.org/10.1016/j.jot. 2018.05.001

17. Gaier ED, Kleppinger A, Ralle M, Mains RE, Kenny AM, Eipper BA (2012) High serum $\mathrm{Cu}$ and $\mathrm{Cu} / \mathrm{Zn}$ ratios correlate with impairments in bone density, physical performance and overall health in a population of elderly men with frailty characteristics. Exp
Gerontol 47(7):491-496. https://doi.org/10.1016/j.exger.2012.03. 014

18. Mutlu M, Argun M, Kilic E, Saraymen R, Yazar S (2007) Magnesium, zinc and copper status in osteoporotic, osteopenic and normal post-menopausal women. J Int Med Res 35(5):692-695. https://doi.org/10.1177/147323000703500514

19. Sadeghi N, Oveisi MR, Jannat B, Hajimahmoodi M, Behzad M, Behfar A (2014) The relationship between bone health and plasma zinc, copper lead and cadmium concentration in osteoporotic women. J Environ Health Sci Eng 12(1):125. https://doi.org/10. 1186/s40201-014-0125-3

20. Dermience M, Lognay G, Mathieu F, Goyens P (2015) Effects of thirty elements on bone metabolism. J Trace Elem Med Biol 32:86-106. https://doi.org/10.1016/j.jtemb.2015.06.005

21. Khan AN (2021) Osteoporosis imaging. Medscape Drugs \& Diseases. Updated Jan 19, 2021. https://emedicine.medscape.com/ article/393602-overview

22. Beck TJ (2007) Extending DXA beyond bone mineral density: understanding hip structure analysis. Curr Osteoporos Rep 5(2):49-55. https://doi.org/10.1007/s11914-007-0002-4

23. Crabtree N, Lunt M, Holt G, Kröger H, Burger H, Grazio S, Khaw KT, Lorenc RS, Nijs J, Stepan J, Falch JA, Miazgowski T, Raptou P, Pols HA, Dequeker J, Havelka S, Hoszowski K, Jajic I, Czekalski S, Lyritis G, Silman AJ, Reeve J (2000) Hip geometry, bone mineral distribution, and bone strength in European men and women: the EPOS Study. Bone 27(1):151-159. https://doi.org/10. 1016/s8756-3282(00)00300-8

24. Harrington JM, Young DJ, Essader AS, Sumner SJ, Levine KE (2014) Analysis of human serum and whole blood for mineral content by ICP-MS and ICP-OES: development of a mineralomics method. Biol Trace Elem Res 160(1):132-142. https://doi.org/10. 1007/s12011-014-0033-5

25. Krachler M, Rossipal E, Micetic-Turk D (1999) Concentrations of trace elements in sera of newborns, young infants, and adults. Biol Trace Elem Res 68(2):121-135. https://doi.org/10.1007/BF027 84401

26. Silk LN, Greene DA, Baker MK (2015) The effect of calcium or calcium and vitamin d supplementation on bone mineral density in healthy males: a systematic review and meta-analysis. Int J Sport Nutr Exerc Metab 25(5):510-524. https://doi.org/10.1123/ijsnem. 2014-0202

27. Tzaphlidou M, Zaichick V (2003) Calcium, phosphorus, calciumphosphorus ratio in rib bone of healthy humans. Biol Trace Elem Res 93:63-74. https://doi.org/10.1385/BTER:93:1-3:63

28. Tzaphlidou M (2008) Bone architecture: collagen structure and calcium/phosphorus maps. J Biol Phys 34:39-49. https://doi.org/ 10.1007/s10867-008-9115-y

29. Granchi D, Caudarella R, Ripamonti C, Spinnato P, Bazzocchi A, Massa A, Baldini N (2018) Potassium citrate supplementation decreases the biochemical markers of bone loss in a group of osteopenic women: the results of a randomized, double-blind, placebo-controlled pilot study. Nutrients 10(9):1293. https://doi. org/10.3390/nu10091293

30. Karp HJ, Ketola ME, Lamberg-Allardt CJE (2009) Acute effects of calcium carbonate, calcium citrate and potassium citrate on markers of calcium and bone metabolism in young women. $\mathrm{Br}$ J Nutr 102(9):1341-1347. https://doi.org/10.1017/S000711450 9990195

31. Macdonald HM, Black AJ, Aucott L, Duthie G, Duthie S, Sandison R, Hardcastle AC, Lanham New SA, Fraser WD, Reid DM (2008) Effect of potassium citrate supplementation or increased fruit and vegetable intake on bone metabolism in healthy postmenopausal women: a randomized controlled trial. Am J Clin Nutr 88(2):465-474. https://doi.org/10.1093/ajcn/88.2.465

32. Verbalis JG, Barsony J, Sugimura Y, Tian Y, Adams DJ, Carter EA, Resnick HE (2010) Hyponatremia-induced osteoporosis. J 
Bone Miner Res 25(3):554-563. https://doi.org/10.1359/jbmr. 090827

33. Zofkova I, Davis M, Blahos J (2017) Trace elements have beneficial, as well as detrimental effects on bone homeostasis. Physiol Res 66(3):391-402. https://doi.org/10.33549/physiolres.933454

34. Fleury C, Petit A, Mwale F, Antoniou J, Zukor DJ, Tabrizian M, Huk OL (2006) Effect of cobalt and chromium ions on human MG-63 osteoblasts in vitro: morphology, cytotoxicity, and oxidative stress. Biomaterials 27(18):3351-3360. https://doi.org/10. 1016/j.biomaterials.2006.01.035

35. Soudani N, Amara IB, Troudi A, Bouaziz H, Boudawara T, Zeghal $\mathrm{N}$ (2011) Oxidative stress induced by chromium (VI) in bone of suckling rats. Toxicol Ind Health 27(8):724-734. https://doi.org/ 10.1177/0748233710395992

36. Ceylan MN, Akdas S, Yazihan N (2021) Is zinc an important trace element on bone-related diseases and complication? A metaanalysis and systematic review from serum level, dietary intake, and supplementary aspects. Biol Trace Elem Res 199:535-549. https://doi.org/10.1007/s12011-020-02193-w

37. He YF, Ma Y, Gao C, Zhao GY, Zhang LL, Li GF, Pan YZ, Li K, Xu YJ (2013) Iron overload inhibits osteoblast biological activity through oxidative stress. Biol Trace Elem Res 152(2):292-296. https://doi.org/10.1007/s12011-013-9605-Z

38. Dowd TL, Rosen JF, Mints L, Gundberg CM (2001) The effect of $\mathrm{Pb}(2+)$ on the structure and hydroxyapatite binding properties of osteocalcin. Biochim Biophys Acta 1535(2):153-163. https://doi. org/10.1016/s0925-4439(00)00094-6

39. Zaichick S, Zaichick V, Karandashev VK, Moskvina IR (2011) The effect of age and gender on 59 trace-element contents in human rib bone investigated by inductively coupled plasma mass spectrometry. Biol Trace Elem Res 143(1):41-57. https://doi.org/ 10.1007/s12011-010-8837-4

40. Talebi M, Abbasi-Rad S, Malekzadeh M, Shahgholi M, Ardakani AA, Foudeh K, Rad HS (2021) Cortical bone mechanical assessment via free water relaxometry at $3 \mathrm{~T}$. J Magn Reson Imaging 54:1744-1751. https://doi.org/10.1002/jmri.27765

41. Granke M, Does MD, Nyman JS (2015) The role of water compartments in the material properties of cortical bone. Calcif Tissue Int 97:292-307. https://doi.org/10.1007/s00223-015-9977-5

42. Castaño-Betancourt MC, Rivadeneira F, Bierma-Zeinstra S, Kerkhof HJ, Hofman A, Uitterlinden AG, van Meurs JB (2013) Bone parameters across different types of hip osteoarthritis and their relationship to osteoporotic fracture risk. Arthritis Rheum 65(3):693-700. https://doi.org/10.1002/art.37792

43. Hartley A, Hardcastle SA, Frysz M, Parkinson J, Paternoster L, McCloskey E, Poole KES, Javaid MK, Aye M, Moss K, Williams M, Tobias JH, Gregson CL (2021) Increased development of radiographic hip osteoarthritis in individuals with high bone mass: a prospective cohort study. Arthritis Res Ther 23(1):4. https://doi. org/10.1186/s13075-020-02371-0

Publisher's Note Springer Nature remains neutral with regard to jurisdictional claims in published maps and institutional affiliations. 